Fastabiq: Jurnal Studi Islam

ISSN 2723-0228

Vol. 2 No. 1 Bulan Juni Tahun 2021

Halaman 1 - 13

\title{
MENANTI KINERJA KEPALA MADRASAH SEBAGAI HASIL PELATIHAN PARTISIPATIF
}

\author{
DOI : https://doi.org/10.47281/fas.v2i1.23 \\ Yudha Andana Prawira ${ }^{1}$ \\ Balai Diklat Keagamaan Bandung \\ E-mail: yudhaandanaprawira@kemenag.go.id
}

\begin{abstract}
This research is based on the need to improve the proficiency and performance of the Madrasah Principles. The participants of the main Madrasah training already have their respective competencies. A strategy for adult education is therefore needed to promote higher competence. One form of training is known as participatory training. The data obtained were then analyzed using a quantitative approach so that some results could be reported, the results of the training which, in addition to the competence of the head of the madrasah, also included a tendency towards positive results as a result of the participatory training found other things that could improve the performance of this madrasah school principal influenced by work experience and educational background factors. Other results suggest that the proficiency of madrasah school principals who are in the moderate madrasa class category may be different from the proficiency and performance of madrasah principals who are in the high madrasa category due to their different educational backgrounds -Class lie, exceeds. These are the results of this analysis as an application of the participatory training model in the training of Madrasah school leaders.
\end{abstract}

Keywords: Madrasah Principles, competency; participative training

\begin{abstract}
Abstrak
Penelitian ini didasari atas perlunya peningkatan kompetensi dan kinerja kepala madrash. Peserta pelatihan kepala madrasah telah memiliki kompetensi masing-masing, karena itu, untuk mendorong kompetensi yang lebih tinggi dibutuhkan strategi pelatihan orang dewasa. Salah satu bentuk pelatihannya dikenal dengan sebutan pelatihan partisipatif. Data yang didapatkan selanjutnya dianalisis dengan pendekatan kuantitatif, maka dapat dikemukakan beberapa hasil, temuan hasil pelatihan yang antara lain bahwa selain kompetensi kepala madrasah yang menunjukkan kecenderungan hasil positif sebagai akibat pelatihan partisipaitf, juga ditemukan beberapa hal lain yang bisa meningkatkan kinerja kepala madrasah ini yang dipengaruhi oleh faktor pengalaman kerja dan latar belakang pendidikan. Temuan lainnya menunjukkan bahwa bisa terjadi kompetensi kepala madrasah yang berada pada kategori madrasah sedang melebihi kompetensi dan kinerja daripada kepala madrasah yang berada pada kategori madrasah tinggi yang disebabkan berbeda latar belakang pendidikan. Demikian temuan dan hasil analisis ini, sebagai dampak dari sebuah aplikasi atas model pelatihan partisipatif dalam pelatihan kepala madrasah pelatihan.
\end{abstract}

Kata Kunci: kepala madrasah; kompeten; pelatihan partisipatif 


\section{Fastabiq: Jurnal Studi Islam \\ ISSN 2723-0228}

Vol. 2 No. 1 Bulan Juni Tahun 2021

\section{PENDAHULUAN}

Abad ke-21 diistilahkan dengan abad pengetahuan dan teknologi. Sebagaimana dikemukan Mukhadis dalam Wijaya bahwa dalam zaman ini, semua alternatif kebutuhan hidup dalam berbagai kegiatan harus berbasis pengetahuan ${ }^{1}$. Upaya pemenuhan bidang pendidikan harus berdasarkan pengetahuan dan teknolgi dalam segala akpek kehidupan, termasuk dalam bidang pendidikan ${ }^{2}$

Termasuk dalam dunia pendidikan, harus mengikuti perkembangan masa kini. Zubaidah menyampaikan sebagaimana dikutip dari Unesco bahwa kehidupan pada abad ini membutuhkan berbagai keterampilan, karena itu. diharapkan pendidikan dapat meningkatkan peserta didik dalam menguasai beragam keterampilan agar menjadi pribadi yang bisa bertahan dalam hidup. Keterampilan yang penting di abad ini sesuai dengan empat pilar kehidupan dari Unesco yang dikutip Zubaidah bahwa "learning to know", "learning to do", "learning to be", dan "learning to live together" ${ }^{3}$. Pernyataan Zubaidah ini menunjukkan bahwa pada saat ini Pendidikan bertujuan bukan sekedar mencapai kompetensi yang telah ditetaokan kurikulum, namun juga diharapkan dapat membawa peserta didik untuk memahami apa yang mereka ketahui (aspek kognitif), agar peserta didik dapat melakukan yang telah diketahuinya (aspek ketrampilan), menjadikan peserta didik mampu mencapai cita-citanya, dan menjadikan peserta didik mampu berkehidupan dalam masyarakat dengan menyesuaikan perkembangan global. Sebagaimana pula pernyataan Nurihsan dalam Prawira, bahwa salah satu tujuan utama Pendidikan secara menyeluruh atau kaffah adalah memanusiakan manusia sehingga bisa menjadi salah satu pendorong pembangunan peradaban bangsa. ${ }^{4}$

Ulasan tersebut merupakan analisis secara makro dunia Pendidikan. Namun, dalam pendidikan secara mikro, maka yang menjadi ujung tombaknya adalah pengelola pendidikan, yakni sekolah/madrasah. Beberapa penelitian tentang peran sekolah/madrasah sebagai ujung tombak pendidikan antara lain disampaikan ${ }^{5}$, Wijaya ${ }^{6}$ yang menjabarkan pentingnya perkembangan Pendidikan dalam abad ke-21, Manik dan Bustomi, Andi ${ }^{7}$ yang menyatakan bahwa dalam pengelolaan Pendidikan sekolah/madrasah yang memiliki peran yang besar adalah kepala sekolah/madrasah, karena kepalalah yang mampu memotivasi kinerja seluruh guru. Sementara itu, Kusbudiyah $^{8}$ menjabarkan bahwa kompetensi supervisi kepala sekolah/madrasah berperan dalam meningkatan kemampuan pedagogis guru. Hal senada juga disampaikan dalam hasil penelitian Nurhilaliati ${ }^{9}$, dan Novita $^{10}$. Berdasarkan hasil telaah pustaka terhadap beberapa penelitian tentang pendidikan tersebut, peneliti dalam artikel ini ingin mengungkapkan kompetensi dan kinerja pengelola Pendidikan setelah mengikuti pelatihan kepala madrasah. Bahwa penelitian-penelitian terhadap kinerja kepala sekolah/madrasah sebagaimana telah dituliskan tersebut, semuanya menyebutkan kepala sekolah/madrasah menjadi ujung tombak pengembangan sekolah/madrsah. Maju mundurnya madrasah banyak dipengaruhi oleh kompetensi kepalanya. Jika kepala madrasahnya memiliki kompetensi yang mumpuni sesuai dengan ketentuan dalam Peraturan Menteri Pendidikan dan Kebudayaan, maka akan membawa kepada kemajuan madrasah tersebut, hal ini berlaku sebaliknya. 


\section{Fastabiq: Jurnal Studi Islam \\ ISSN 2723-0228}

Vol. 2 No. 1 Bulan Juni Tahun 2021

Pengelola Pendidikan memiliki peran yang sangat dominan dalam menentukan kebijakan pengembangan sekolah/madrasahnya. Di Indonesia, pengelola pendidikan ini biasa juga disebut dengan istilah kepala sekolah/madrasah. Mengingat pentingnya peran kepala sekolah/madrasah, sehingga pemerintah mengaturnya dalam bentuk peraturan Menteri Pendidikan dan Kebudayaan. Hal ini dibutuhkan untuk penyamaan persepsi dalam pengelolaan persekolah/madrasah. Peraturan Menteri yang pertama adalah tentang standar kualifikasi dan standar kompetensi kepala sekolah/madrasah ${ }^{11}$. Dalam peraturan ini ditetapkan bahwa secara kualifikasi seseorang bisa diangkat menjadi kepala sekolah/madrasah jika memenuhi persyaratan misalnya serendahrendahnya berijazah S-1 dengan minimal masa kerja mulai dari 3 tahun untuk kepala RA/TK, atau masa kerja minimal 6 tahun untuk kepala MI, MTs, dan MA. Jika untuk madrasah negeri sekurangkurangnya memiliki jabatan guru muda atau golongan III/c. Sementara itu, dari aspek syarat kompetensi, seorang kepala sekolah/madrasah harus memiliki kompetensi kepribadian, majerial, kewirausahaan, supervise, dan social ${ }^{12}$.

Khusus untuk sekolah/madrasah yang diselenggarakan dan dibina oleh Kementerian Agama, diatur tersendiri yaitu dengan Peraturan Menteri Agama nomor 24 tahun $2018^{13}$. Dalam peraturan Menteri Agama ini diatur mulai dari persyaratan hingga sertifikasi kepala madrasah. Sertifikasi dibutuhkan untuk meningkatan kualitas kinerja kepala madrasah. Dengan sertifikasi kepala madrasah juga dapat meng-update, pengetahuan dan keterampilan kepala madrasah.

Penyesuaian kinerja kepala madrasah tidak sekedar dalam memenuhi peraturan dari pemerintah pusat dan daerah, juga untuk menyesuaikan dengan perkembangan Pendidikan secara mendunia. Saat ini, Pendidikan telah memasuki era baru dengan istilah Pendidikan abad 21. Hal yang perlu diperhatikan kepala madrasah dalam Pendidikan abad 21 ini antara lain tentag perlunya mencipatan lingkungan Pendidikan yang bisa membuat siswa menyenangkan dan tidak merasa terbelenggu. Kemudian mem membuat jejaring kerja (kolaborasi) ${ }^{14}$

Perkembangan sekolah/madrasah sangat dipengaruhi oleh manajer sekolah/madrasah, dalam hal ini tentu saja adalah kepala madrasah. Tugas kepala sekolah/madrasah tidak cukup sekedar sesuai standar kompetensi maupun kualifikasi dari permendikbud. Dibutuhkan kepala madrasah yang cerdas dan kreatif untuk membangun madrasah yang dikelolanya. Hal ini sebagaimana yang dikemukakan Salam bahwa salah satu upaya kepala madrasah mengembangkan profesionalisme guru bukan hanya mengerjakan kompetensi yang ada, dan bukan hanya mempengaruhi para guru untuk mengamalkan kompetensinya, akan tetapi kepemimpinannya harus lebih dari itu, antara lain inovatif dan kreati ${ }^{15}$. Kepribadian kepala sekolah juga dapat membentuk keberhasilan peserta didik. ${ }^{16}$ Kompetensi kepala sekolah sebagai seorang pemimpin perlu diperkuat juga dengan asepk etika dan etnik. ${ }^{17}$ dan Selain itu, untuk menjaga kinerja dan kompetensi kepala madrasah, perlu pula pelaksanaan evaluasi secara berkesinambungan.

Dalam hal ini evaluasi bisa dilakukan secara mandiri/self evaluation maupun evaluasi oleh pemangku kebijakan kinerja kepala madrasah, dalam hal ini adalah peran pengawas madrasah yang 


\section{Fastabiq: Jurnal Studi Islam \\ ISSN 2723-0228}

Vol. 2 No. 1 Bulan Juni Tahun 2021

disampaikan Prawira ${ }^{18}$, bahwa untuk menjaga konsistensi kinerja kepala madrasah dibutuhkan instrument dan evaluator bagi kepala, dalam hal ini adalah para pengawas sekolah. Pengawas sekolah inilah yang nantinya mengawal kinerja kepala sekolah/madrasah. Penelitian Berdiati mengungkapkan bahwa untuk mempimpin sekolah/madrsah dibutuhkan kepala madrasah yang memiliki kemampuan dalam pengembangan diri maupun pengembangan profesinya, sehingga bisa menjadi kepala yang inovatif dan kreatif Berdiati $^{19}$.

Dalam upaya meningkatkan kompetensi dan kinerja kepala madrasah ini, dibutuhkan upaya pelatihan yang mendukung pada pembelajaran orang dewasa. Salah satu model pelatihan ini adalah pelatihan partisipatif. Pelatihan partisipatif dipandang memadai untuk melatih kepala madrasah dalam meningkatkan kompetensi maupun kinerjanya karena beberapa tahapan dalam pelatihan partisipatif ini disesuaikan dengan kebutuhan peserta pelatihan. Beberapa penelitian tentang manfaat pelatihan partisipatif telah dikemukakan antara lain oleh Setiawan ${ }^{20}$, Permanasari $^{21}$ dan Mawardi ${ }^{22}$.

Secara garis besarnya tahapan atau sintak pelaksanaan pelatihan partisipatif ini adalah ditempuh melalui 6 langkah kegiatan sebagaimana yang dikemukakan Mones, yaitu: (1) Tahap Pembinaan Keakraban, (2) Tahap Identifikasi Kebutuhan, Sumber dan Kemungkinan Hambatan, (3) Tahap Perumusan Tujuan Belajar, (4) Tahap Penyusunan Program kegiatan Belajar, (5) Tahap Pelaksanaan Kegiatan Pembelajaran, (6) Tahap Penilaian Proses, Hasil dan Pengaruh Kegiatan Pembelajaran ${ }^{23}$.

Langkah-langkah tersebut dianggap tepat untuk pelatihan dan pembelajaran orang dewasa, karena salah satu motivasi orang dewasa untuk belajar dan berlatih adalah atas dasar kebutuhan dan keinginan mereka. Malik menyatakan bahwa Keterlibatan diri (ego peserta didik) adalah kunci keberhasilan dalam pembelajaran orang dewasa. untuk itu pendidik hendaknya mampu membantu peserta didik untuk: (a) mendefinisikan kebutuhan belajarnya, (b) merumuskan tujuan belajar, (c) ikut serta memikul tanggung jawab dalam perencanaan dan penyusunan pengalaman belajar, dan (d) berpartisipasi dalam mengevaluasi proses dan hasil kegiatan belajar. Dengan demikian setiap pendidik harus melibatkan peserta didik seoptimal mungkin dalam kegiatan pembelajaran ${ }^{24}$. Dengan melibatkan factor psikologi dan ego peserta pelatihan diharapkan dapat meningkatkan motivasi sehingga akan berdampak pula pada hasil pelatihan. Sehingga pada akhirnya diharapkan bahwa setelah kepala madrasah ini mengikuti pelatihan dengan model partisipatif, kepala madrasah akan memiliki motivasi yang kuat dalam mengembangkan kinerja seluruh civitas akademika di sekolahnya.

Namun demikian, dalam pelatihan yang pesertanya termasuk orang dewasa, bahwa kepala sekolah/madrasah termasuk kategori ini, yang bisa menjadi kendala untuk pelatihan dan pembelajaran orang dewasa adalah keengganan untuk dinilai atau dievaluasi. Seorang dewasa biasanya memiliki otoritas dan prerogative di wilayah kerjanya. Sehingga dengan merasa bahwa wilayah kerja kepala sekolah/madrasah merupakan tanggung jawabnya, kepala merasa bahwa kepala merupakan urutan tertinggi dalam lingkungannya, maka akan menjadi lebih menonjolkan egonya. Karena ego sebagai kepala sekolah/madrasah ini, menjadikan enggan untuk diawasi dan 


\section{Fastabiq: Jurnal Studi Islam \\ ISSN 2723-0228}

Vol. 2 No. 1 Bulan Juni Tahun 2021

dieavluasi. Dalam hal ini juga sesuai dengan hasil penelitian Hanum tentang evaluasi diklat di Kementerian Agama, bahwa penyelenggaraan pelatihan harus sesuai kebutuhan pengguna (user) ${ }^{25}$. Hal ini pula yang menjadi salah satu alasan pemilihan model pelatihan partisipatif untuk penyelenggaran pelatihan peningkatan kompetensi kepala madrasah,

Berdasarkan latar belakang tersebut tentang perlunya peningkatan kompetensi dan kinerj kepala madrasah ini, maka peneliti mengajukan permasalahan sebagai suatu upaya meningkatkan kompetensi dan kinerja kepala madrasah, berupa rumusan masalah "Apakah penerapan pelatihan partisipatif dapat berpengaruh terhadap kompetensi dan kinerja kepala madrasah?" Hasil pemerolehan data yang dari peserta diklat kepala madrasah ini, dijabarkan berupa analisis deskriptif, yang hasilnya terbagi atas tiga kelompok jenis madrasah, yaitu kepala pada madrasah tinggi, madrasah menengah, dan madrasah rendah, yang pembagian ketiga jenis ini berdasarkan data dari Badan Akreditasi Nasional Sekolah/Madrasah (BAN-S/M) Provinsi Jawa Barat dari sudut pandang hasil akreditasi sekolah/madrasah.

\section{METODE PENELITIAN}

Penelitian ini menelaah peserta pelatihan kepala madrasah di lingkungan Balai Diklat Keagamaan bandung pada tahun 2020. Sampel yang dijadikan subjek penelitian diambil secara purposif, mengingat keterbatasan ruang dan waktu yang tersedia. Pada tahun 2020, Balai Diklat keagamaan Bandung melaksanakan pelatihan kepala madrasah ibtidaiyah sebanyak 34 angkatan, terdiri atas masing-masing 30 orang, sehingga populasi kepala MI adalah 1020 orang. Sampel yang dipilih dari 1020 tadi terdiri atas 5 (lima) angkatan Pelatihan Kepala Madrasah Ibtidaiyah (selanjutnya disebutkan kepala madrasah) di Lingkungan Kantor Wilayah Kementerian Agama Jawa Barat periode Juli-September 2020 yang diselenggarakan oleh Balai Pendidikan dan Keagamaan Bandung. Masing-masing Angkatan berjumlah 30 orang, sehingga subjek penelitian berjumlah 150 orang kepala madrasah. Sesuai dengan rumusan dan pertanyaan masalah bahwa penelitian ini untuk menjawab tentang pengaruh pelatihan dengan model pelatihan partisipatif terhadap peningkatan kompetensi dan kinerja kepala madrasah, peserta pelatihan Peningkatan Kompetensi Kepala Madrasah di Lingkungan Kantor Wilayah Kementerian Agama Provinsi Jawa Barat tahun $2019^{26}$.

Penelitian ini menggunakan pendekatan kuantitatif deskriptif dengan metode penelitian tipe one shot case study. dengan menerapkan model pelatihan partisipatif. Metode penelitian ini merujuk pada pendapat $\mathrm{Yin}^{27}$. Juga yang disampaikan $\operatorname{Rahmat}^{28}$. Tahap pertama dari penelitian yaitu dengan menentukan unit-unit eksperimen seperti pengkategorian madrasah tinggi, sedang dan menengah. Adapun klasifikasi pengkategorian didasarkan pada peringkat sekolah berdasarkan data yang diperoleh dari Pusat Data Kemdikbud ${ }^{29}$.

Untuk kriteria kesetaraan peserta pelatihan diberikan tes awal tentang kompetensi dan kinerja kepala madrasah sesuai Peraturan Menteri Agama dan Menteri Pendidikan dan Kebudayaan tentang kepala sekolah/madrasah. Instrumen disusun berdasarkan Peraturan Menteri Pendidikan nomor 16 tahun 2007, yang mencakup antara lain bahwa kompetensi kepala sekolah/madrasah adalah 


\section{Fastabiq: Jurnal Studi Islam \\ ISSN 2723-0228}

Vol. 2 No. 1 Bulan Juni Tahun 2021

kompetensi kepribadian, manajerial, supervise, kewirausahaan, dan kompetensi socia ${ }^{30} \mathrm{I}$. Sementara itu, untuk instrument proses pelatihan, menggunakan data dari evaluasi pelatihan Kirk Patrik dalam Utomo dkk, yaitu terdiri atas empat level, level reaksi, level pembelajaran, level perilaku, dan level hasil ${ }^{31}$.

\section{HASIL DAN PEMBAHASAN}

Sesuai dengan permasalahan sebagaimana yang telah dikemukakan pada bagian pendahuluan, bahwa penelitian ini untuk mengetahui kinerja kepala madrasah yang sesuai dengan kompetensi kepala sekolah/madrasah sebagai dampak dari pelaksanaan pelatihan kepala sekolah/madrasah yang menggunakan pola pelatihan partisipatif. Berikut beberapa temuan yang didapatkan. Pertama, temuan tentang kompetensi kepala madrasah dilihat dari aspek peringkat madrasah. Bahwa setelah mengikuti pelatihan partisipatif para peserta ini mengalami beberapa perubahan, antaralain dalam kompetensinya sebagai kepala madrasah. Dalam kajian ini, kompetensi yang dimiliki kepala madrasah ini dibagi dalam tiga bagian. Bagian tersebut adalah ditinjau dari jenis atau peringkat madrasahnya. Peringkat ini berdasarkan data dari BAN-S/M Provinsi Jawa Barat. Peringkat ini berupa madrasah level tinggi, madrasah level sedang/menengah, dan madrasah level rendah. Temuannya dapat diamati dalam grafik di bawah ini.

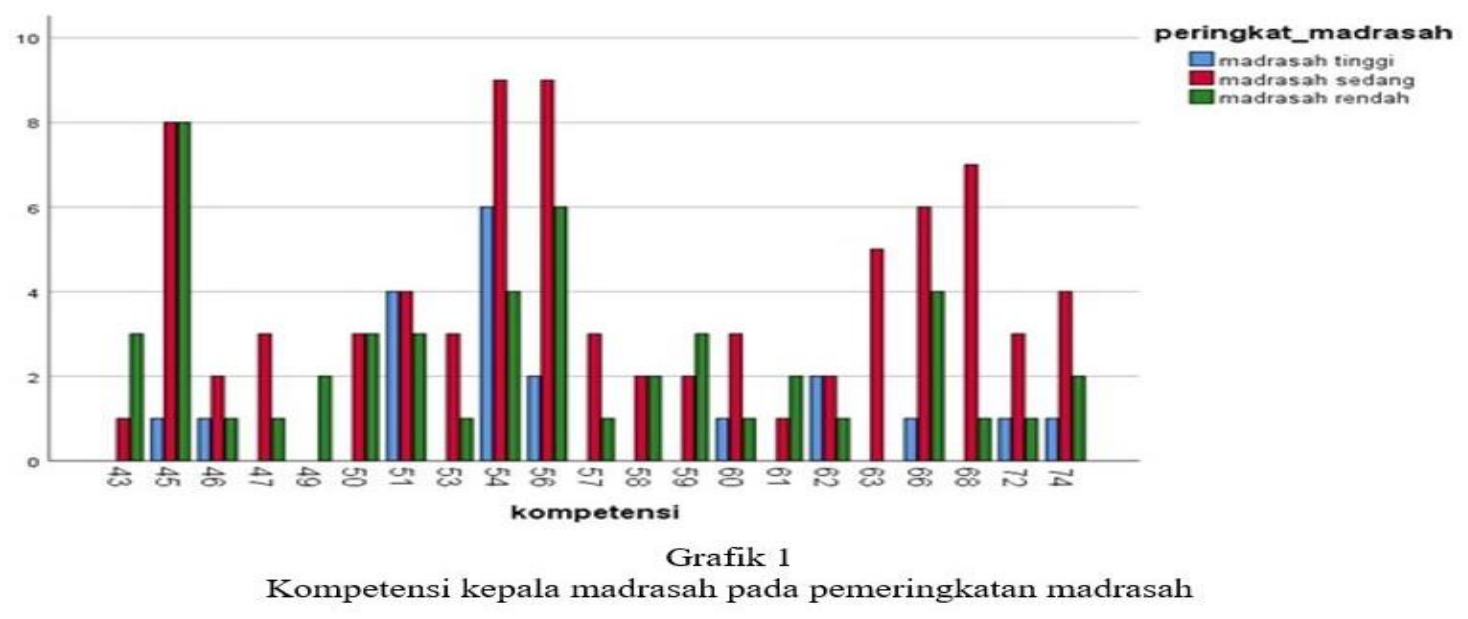

Berdasarkan grafik tersebut dapat dideskripsikan bahwa kepala madrasah yang memiliki kompetensi menonjol berasal dari kelompok madrasah level sedang/menengah. Yang menjadi anomali justru kompetensi kepala madrasah yang masih dianggap belum memadai berasal dari madrasah level tinggi. Artinya bahwa kepala madrasah yang berasal dari kelompok madrasah yang dianggap tinggi (hasil akreditasi BAN-S/M) justru kompetensinya tidak begitu baik. Kepala madrasah yang berasal dari madrasah tinggi ini dari aspek perolehan kompetensi ternyata di bawah rata-rata kompetensi kepala madrasah yang berasal dari madrasah rendah.

Mengingat terjadinya anomali ini, maka diperlukan data tambahan sebagai triangulasi, untuk mencari penyebab terjadinya anomali ini. Peneliti, melakukan penggalian dengan mengunakan 


\section{Fastabiq: Jurnal Studi Islam \\ ISSN 2723-0228}

Vol. 2 No. 1 Bulan Juni Tahun 2021

crosstabs. Hasil penghitungan melalui aplikasi SPSS didapat bahwa Pada tabel Chi Square Test menunjukan hasil dari rumus chi square (chi kuadrat) hitung sebesar 47,567 hasil ini membuktikan hipotesis dibuat. Berdasarkan hasil analisis SPSS Asymp.sig(2-sided) sebesar $=0,022$. Ternyata $\alpha=$ $0,05$ lebih besar dari nilai Asymp.sig(2-sided) atau [0,05 $>0,022]$. Artinya terdapat hubungan yang signifikan antara kompetensi kepala madrasah dengan latar belakang pendidikan.

Hal ini sejalan juga dengan tabel silang antara pendidikan dan peringkat madrasah, hasil tabulasinya adalah sebagai berikut.

\begin{tabular}{|c|c|c|c|c|c|}
\hline & & \multicolumn{3}{|c|}{ pendidikan } & \multirow[b]{2}{*}{ Total } \\
\hline & & SMA & Sarjana & Pascasarjana & \\
\hline \multirow[t]{4}{*}{ madrasah tinggi } & Count & 1 & 8 & 11 & 20 \\
\hline & $\begin{array}{l}\% \text { within } \\
\text { peringkat_madrasah }\end{array}$ & $5.0 \%$ & $40.0 \%$ & $55.0 \%$ & $100.0 \%$ \\
\hline & $\%$ within pendidikan & $9.1 \%$ & $12.3 \%$ & $14.9 \%$ & $13.3 \%$ \\
\hline & $\%$ of Total & $0.7 \%$ & $5.3 \%$ & $7.3 \%$ & $13.3 \%$ \\
\hline \multirow[t]{4}{*}{ madrasah sedang } & Count & 6 & 34 & 40 & 80 \\
\hline & $\begin{array}{l}\text { \% within } \\
\text { peringkat_madrasah }\end{array}$ & $7.5 \%$ & $42.5 \%$ & $50.0 \%$ & $100.0 \%$ \\
\hline & $\%$ within pendidikan & $54.5 \%$ & $52.3 \%$ & $54.1 \%$ & $53.3 \%$ \\
\hline & $\%$ of Total & $4.0 \%$ & $22.7 \%$ & $26.7 \%$ & $53.3 \%$ \\
\hline \multirow[t]{4}{*}{ madrasah rendah } & Count & 4 & 23 & 23 & 50 \\
\hline & $\begin{array}{l}\% \text { within } \\
\text { peringkat_madrasah }\end{array}$ & $8.0 \%$ & $46.0 \%$ & $46.0 \%$ & $100.0 \%$ \\
\hline & $\%$ within pendidikan & $36.4 \%$ & $35.4 \%$ & $31.1 \%$ & $33.3 \%$ \\
\hline & \% of Total & $2.7 \%$ & $15.3 \%$ & $15.3 \%$ & $333 \%$ \\
\hline
\end{tabular}

Tabel silang Pendidikan dan Peringkat Madrasah

Berdasarkan tabel silang (crosstabs) antara latar belakang pendidikan kepala madrasah dengan peringkat madrasah, sangat jelas bahwa madrasah level menengah/sedang memiliki kepala madrasah yang berpendidikan tinggi(S-1 dan S-2) sebanyak 80 dari 150 sampel peserta pelatihan. Karena itu, dapat dikatakan terjadinya anomali bahwa kompetensi kepala madrasah lebih banyak di level madrasah menengah karena memiliki tingkat pendidikan yang lebih tinggi daripada madrasah yang berada pada level tinggi maupun rendah. Namun yang menjadi perhatian adalah pada madrasah yang termasuk kategori level tinggi, ternyata jumlah kepala madrasah (19 orang S-1 dan S-2) yang memiliki latar belakang pendidikan tinggi jauh di bawah madrasah yang berkategori rendah (46 orang S-1 dan S-2). Hal ini pula yang menyebabkan kompetensi kepala madrasah kategori tinggi menjadi di bawah kompetensi kepala madrasah dengan kategori rendah.

Temuan berikutnya temuan berupa kinerja kepala madrasah yang ditijau dari sudut peringkat madrasah sebagai hasil dari pelatihan peningkatan kompetensi kepala madrsah yang menggunakan model pelatihan partisipatif. Di bawah ini adalah gambaran temuan pada tingkat kinerja kepala madrasah. 


\section{Fastabiq: Jurnal Studi Islam \\ ISSN 2723-0228}

Vol. 2 No. 1 Bulan Juni Tahun 2021

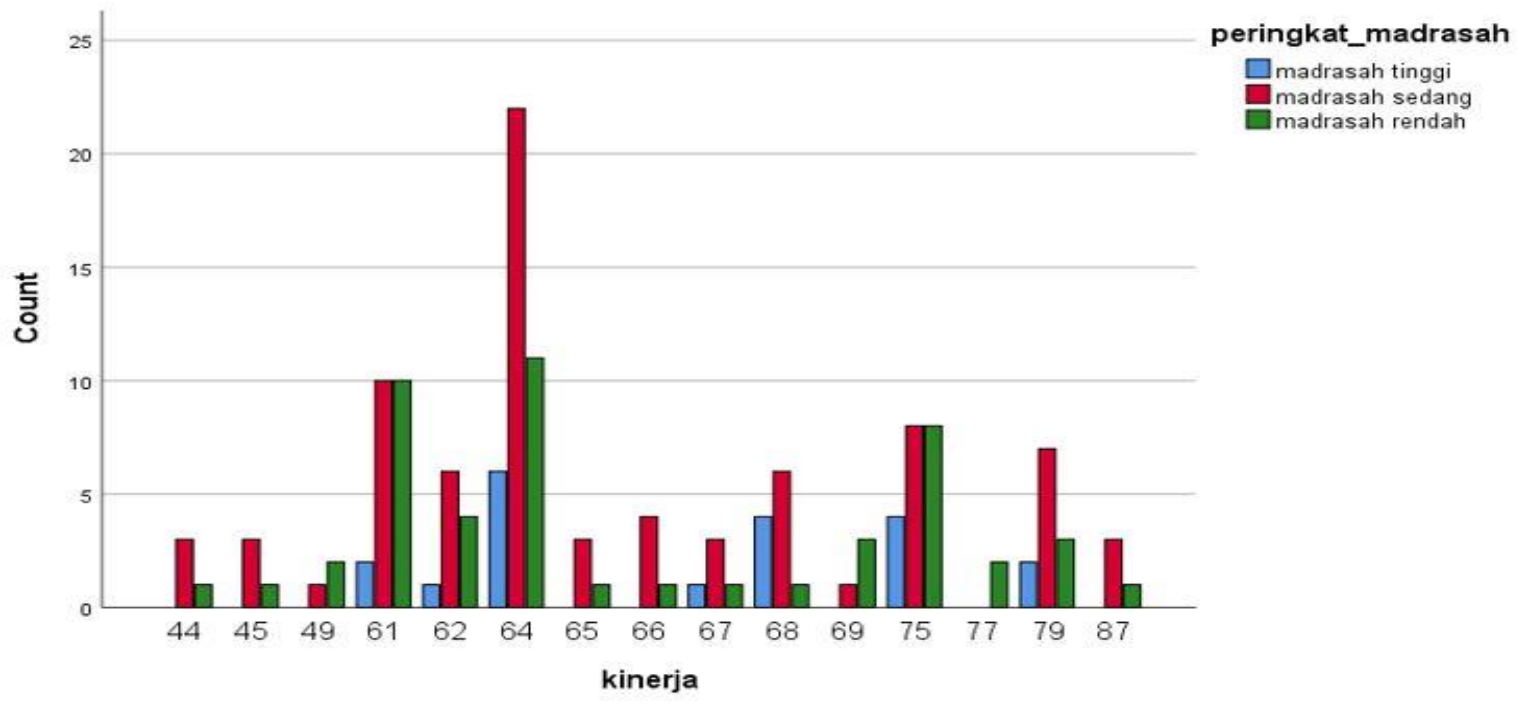

Grafik 2

Kinerja kepala madrasah pada pemeringkatan madrasah

Berdasarkan grafik tersebut dapat dideskripsikan bahwa dalam hal kinerja kepala madrasah yang berada pada kategori level tinggi masih lebih baik dibandingkan dengan kepala madrasah pada level sedang dan rendah. Hal ini tergambarkan pada nilai terendah pada angka 61 poin dan tertinggi pada angka 79 poin. Sementara itu, untuk kepala madrasah yang berada kategori madrasah level sedang dan rendah, hanya memiliki poin 44. Namun demikian, dari segi rata-rata dan jumlah lebih baik kepala madrasah yang berada pada kategori madrasah sedang.

Sementara itu, sebagai akhir dari keseluruhan penelitian ini adalah untuk mengetahui berhasil tidaknya penggunaan model pelatihan partisipatif pada pelatihan peningkatan kompetensi kepala madrasah, berikut hasil penghitungan secara statistik hasil analisis kompetensi kepala madrasah sebelum dan setelah mengikuti pelatihan. Untuk penghitungan ini peneliti menggunakan alat bantu aplikasi SPSS.

Berdasarkan tabel hasil hitung tersebut, bahwa korelasi: Nilai Korelasi antara 2 variabel tersebut: Hasil 0,117 artinya hubungan kuat dan positif. Dengan demikian tingkat signifikansi hubungan: Hasil 0,000 artinya signifikan pada level 0,01. $T=$ nilai $t$ hitung: hasil 1,000: yang dibandingkan dengan $t$ tabel pada DF 148. Apabila $t$ hitung $>t$ tabel: signifikan. Sementara itu, tingkat signifikasi Sig. (2-tailed): Nilai probabilitas/p value uji T Paired: Hasil $=0,001$. Artinya: Tidak ada perbedaan antara sebelum dan sesudah perlakuan. Sebab: Nilai $p$ value $>0,05(95 \%$ kepercayaan). Dengan Mean:-41,100. Bernilai negatif: Artinya terjadi kecenderungan peningkatan sesudah perlakuan. Simpulan sementara berdasarkan hasil hitung statistik dengan dugaan sementara penelitian ini dapat disebutkan bahwa terjadi peningkatan pada aspek kompetensi dan kinerja kepala madrasah yang mengikuti pelatihan peningkatan kompetensi kepala madrasah pada periode Juli-September 2020. 


\section{Fastabiq: Jurnal Studi Islam \\ ISSN 2723-0228}

Vol. 2 No. 1 Bulan Juni Tahun 2021

\section{SIMPULAN}

Penelitian ini menyimpulkan bahwa pelatihan partisipatif untuk kepala madrasah yang dilaksanakan di Balai Diklat Keagamaan Bandung memiliki dampak yang cukup baik terhadap peningkatan kompetensi kepala madrasah. Namun peningkatan kompetensi kepala madrasah sebagai dampak pelatihan partisipatif ini, juga dipengaruhi beragam factor, antara lain, latar belakang peserta pelatihan dan jenis atau klister madrasah tempat para kepala madrasah ini mengabdi. Hasil pelatihan dapat dilihat dari kompetensi kepala madrasah yang berasal dari kelompok madrasah yang rendah dan sedang, ternyata mampu melebihi kompetensi kepala madrasah yang berasal atau bertugas di kelompok madrasah tinggi. Hal ini, dapat disimpulkan bahwa pelatihan partisipatif untuk kepala madrasah ini mampu mendongkrak kompetensi kepala madrasah dari kelompok rendah.

Demikian penelitian ini, semoga dapat menjadi pencerahan bagi khazanah pengetahuan dan para pengambil kebijakan yang membidangi para kepala madrasah agar lebih kompeten dan berkinerja lebih baik lagi. 


\section{Fastabiq: Jurnal Studi Islam \\ ISSN 2723-0228}

Vol. 2 No. 1 Bulan Juni Tahun 2021

\section{ENDNOTES}

\footnotetext{
${ }^{11}$ Wijaya et.al, "Transformasi Pendidikan Abad 21 sebagai Tuntutan Pengembangan Sumber Daya Manusia di Era Global" Volume 1 Tahun 2016 - ISSN 2528-259X

${ }^{2}$ Estetika Yuni Wijaya, "Transformasi Pendidikan abad 21 sebagai tuntutan pengembangan sumber daya manusia di era global", Prosiding Seminar Nasional Matematika UKM, 2016

${ }^{3}$ Siti Zubaidah, "Keterampilan abad ke-21: keterampilan yang diajarkan melalui pembelajaran", pada Seminar Nasional Pendidikan STKIP Persada Sintang Kalimantan Barat, 2016

${ }^{4}$ Prawira, "GURU SEBAGAI PEMBANGUN PERADABAN BANGSA DALAM PERSPEKTIF PENDIDIKAN", SPS Universitas Pendidikan Indonesia

${ }^{5}$ Wijaya, et.al

${ }^{6}$ Ester Manik dan K. Bustomi, "Pengaruh Kepemimpinan Kepala Sekolah Budaya Organisasi dan Motivasi Kerja terhadap kinerja guru pada SMPN 3 RAncaekek", pada Jurnal Ekonomi, Bisnis, \&Enterpreneurship. 2011

${ }^{7}$ H,A.T\&Andi,"Pengaruh Pengembangan Sumber daya Manusia SD/MI, pada jurna, 2019.

${ }^{8}$ Yayah Kusbudiyah,"Peningkatan Kometensi Kepala RA dalam mengembangkan pembelajran melalui mata diklat pengembangan kompetensi supervisi" pada jurnal Tatar PAsundan Volume XII, 2018

${ }^{9}$ Nurhilaliati, "Kualitas Kepempinan Kepala Madrasah Perempuan di Lingkungan Pondok Pesantren", pada Jurnal Edukasi Balitbangdiklat Kemenag, 2019.

${ }^{10}$ Mona Novita, "Sarana dan Prasarana yang baik menjadi bagian ujung tombak keberhasilan Lembaga Pendidikan Islam", pada jurnal Nur El-Islam Volume 4, 2017

${ }^{11}$ Permendikbud Nomor 6 tahun 2018, tentang tata cara pengangkatan kepala sekolah/madrasah

${ }^{12}$ Permendiknas Nomor 13 tahun 2007, tentang standar kualifikasi dan kompetensi kepala sekolah

${ }^{13}$ Permenag Nomor 24 tahun 2018

${ }^{14}$ Peraturan Presiden Nomor 87 tahun 2017 tentang penguatan Pendidikan karakter

${ }^{15}$ Mochamad F. Salam, "Kepemimpinan Spiritual Kepala Sekolah dalam Mengembangkan Profesionalisme Guru, dalam Jurnal Fastabiq Volume 1, 2017

${ }^{16}$ Purnomo, H., Karim, A., Rahmatullah, A. S., \& Sudrajat, S. Principals' personality, leadership, teachers' job satisfaction and students' achievement. International Journal of Psychosocial Rehabilitation, 24, 8, 2020, 4581-4596.

${ }^{17}$ Karim, A., Mardhotillah, N. F., \& Samadi, M. I. Ethical leadership transforms into ethnic: Exploring new leaders's style of Indonesia. Journal of Leadership in Organizations, 1, 2, 2019, 146-157.

${ }^{18}$ Yudha A. Prawira, "Kompetensi Evakuasi Pendidikan", pada academia.edu, 2016

${ }^{19}$ Ika Berdiati, "PERAN PENGAWAS DALAM PENGEMBANGAN KEPROFESIAN BERKELANJUTAN BAGI GURU" pada Jurnal Tatar Pasundan Volume XIV , 2020

${ }^{20}$ Wahyu E. Setiawan, " Model Pembelajaran PArtisipatif dalam Meningkatkan Kemandirian

Perempuan sebagai Kepala Keluarga", Jurnal Universitas Negeri Palangkaraya, 2015.

${ }^{21}$ E. Permanasari, "Metode Desain PArtisipatif sebagai model pembangunan di DKI Jakarta", pada researchgate, 2017

${ }^{22}$ Mawardi, dkk, "Penerapan Pelatihan PArtisipatif pada kegiatan penulisan dan publikasi karya ilmiah bagi guru SD", pada Jurnal Scholaria Volume 9, tahun 2019

${ }^{23}$ Anselmus Mones, "Penegembangan Pembelajaran Partisipatif untuk Mata Pelajaran Sosiologi Kelas XI SMA Negeri 2 Kefamenanu", pada jurnal 2008.

${ }^{24}$ Malik, et.al

${ }^{25}$ Farida Hanum, "EVALUASI PENYELENGGARAAN DIKLAT DI KEMENTERIAN AGAMA", pada Jurnal Edukasi Balitbang Dlklat Kemenag, 2018.

${ }^{26}$ Balai Diklat Keagamaan Bandung, "Data Alumni Diklat Kepala Madrasah", website bdkbandung.kemenag.go.id.2019

${ }^{27}$ Robert K. Yin, "Discovery the Future of the Case Study, Method in evaluation research", pada researchgate, 1994

${ }^{28}$ A. Rahmat, "Penggunaan permainan devinettes dalam pembelajaran menulis kalimat sederhana Bahasa Perancis", pada respositori UPI, 2015.

${ }^{29}$ Kemdikbud, "Indonesia Educational Statistics in Brief 2016/2017", pada Pusat Data dan Statistik Kemdikbud 2017

${ }^{30}$ Kemdiknas, "Lampiran Permendiknas Nomor 16 Tahun 2007", tentang standar kualifikasi dan kompetensi kepala sekolah/madrasah
} 


\section{Fastabiq: Jurnal Studi Islam}

ISSN 2723-0228

Vol. 2 No. 1 Bulan Juni Tahun 2021

${ }^{31}$ Utomo, dkk, "Evaluasi Pelatihan dengan metode kirk Patrik Analisis" jurnal Telematika, Institut Teknologi Harapan Bangsa Bandung. 


\section{Fastabiq: Jurnal Studi Islam \\ ISSN 2723-0228}

Vol. 2 No. 1 Bulan Juni Tahun 2021

\section{REFERENSI}

Baldwin, T. T., Magjuka, R. J., \& Loher, B. T. 1991. the Perils of Participation: Effects of Choice of Training on Trainee Motivation and Learning. Personnel Psychology, 44(1), 51-65. https://doi.org/10.1111/j.1744-6570.1991.tb00690.x

Berdiati, I. 2020. Sopervisor's Role in Continuing Professional Development for Teacher. Tatar Pasundan: Jurnal Diklat Keagamaan, (14) 1, 38-49.

Dawson, T. E. 2007. A Primer on Experimental and Quasi-Experimental Design A Primer on Experimental and Quasi-Experimental Design, (January 1997), 1-15.

Depdiknas. 2007a. Permendiknas 16 tahun 2007. Djih Kemendiknas, 67(6), 14-21.

Depdiknas. Permendiknas Nomor 13 tahun 2007. 2007.

H, A. T., \& Andi, P. 2019. PENGEMBANGAN SUMBER DAYA MANUSIA SD / MI, 10, 26-50.

Hanum, F. 2018. Evaluasi Penyelenggaraan Diklat Di Kementerian Agama. EDUKASI: Jurnal Penelitian Pendidikan Agama Dan Keagamaan, 16(2), 191-203. https://doi.org/10.32729/edukasi.v16i2.477

Indonesia, P. R. 2017. Peraturan Presiden Republik Indonesia Nomor 87 Tahun 2017.

Kang, L., Chen, W., Petrick, N. A., \& Gallas, B. D. (2015). Comparing two correlated C indices with right-censored survival outcome: A one-shot nonparametric approach. Statistics in Medicine, 34(4), 685-703. https://doi.org/10.1002/sim.6370.

Karim, A., Mardhotillah, N. F., \& Samadi, M. I. 2019. Ethical leadership transforms into ethnic: Exploring new leaders's style of Indonesia. Journal of Leadership in Organizations, 1(2), 146157. https://doi.org/https://doi.org/10.22146/jlo.44625.

Keagamaan, B. D. 2019. 3. data alumni diklat kamad.pdf. Bandung: 2019. Retrieved from https://simlitbangdiklat.kemenag.go.id/simdiklatbalai/peserta/filter_alumni

Kemdikbud, P. D. 2017. Indonesia Educational Statistics in Brief 2016/2017. Jakarta: Kemdikbud.

Kemenag. 2018. Permenag Nomor 24 Tahun 2018 Kepala Madrasah. Jakarta: Kemenag.

Kusbudiah, Y. 2018. Peningkatan Kompetensi Kepala Raudhatul Atfhal (RA) dalam Mengembangkan Pembelajaran melalui Mata Dlklat Pengembangan kompetensi Supervisi, Tatar Pasundan: Jurnal Diklat Keagamaan, (12) 37, 23-31. https://doi.org/https://doi.org/10.38075/tp.v12i32.51

Malik, H. K. 2008. Teori Belajar Andragogi dan Aplikasinya dalam Pembelajaran. Inovasi, 5(2), 1-16.

Manik, E., \& Bustomi, K. 2011. Pengaruh Kepempinan Kepala, Budaya Organisasi, dan Motivasi Kerja terhadap Kinerja Guru pada SMP Negeri 3 Rancaekek, 5(2), 97-107.

Mawardi, M., Kristin, F., Anugraheni, I., \& Rahayu, T. S. 2019. Penerapan Pelatihan Partisipatif Pada Kegiatan Penulisan Dan Publikasi Karya IImiah Bagi Guru SD. Scholaria: Jurnal Pendidikan Dan Kebudayaan, 9(2), 132-137. https://doi.org/10.24246/j.js.2019.v9.i2.p132-137

Mendikbud. 2018. Permendikbud Nomor 6 Tahun 2018. Jakarta: Kemdikbud.

Mones, A. Y. 2008. Pengembangan Pembelajaran Partisipatif untuk Mata Pelajaran Sosiologi Kelas XI SMA Negeri 2 Kefamenanu, 2-3.

Novita, M., Pendahuluan, A., \& El-islam, N. 2017. Sarana dan prasarana yang baik menjadi bagian ujung tombak keberhasilan lembaga pendidikan islam, 4.

Nurhilaliati, N. 2019. Kualitas Kepemimpinan Kepala Madrasah Perempuan Di Lingkungan Pondok Pesantren. EDUKASI: Jurnal Penelitian Pendidikan Agama Dan Keagamaan, 17(1), 57-69. https://doi.org/10.32729/edukasi.v17i1.541

Pellegrino, J. W., \& Hilton, M. L. 2012. Education for Life and Work: DevelopingTranserable Knowlegde and Skills in the 21st Century. (J. W. Pellegrino, Ed.). Washington DC. Retrieved from https://books.google.co.id/books?hl

Permanasari, E. 2018. Metode Desain Partisipatif sebagai Meodel Pembangunan 6 RPTRA DKI Jakarta. Tangerang Selatan: UPJ Press.

Purnomo, H., Karim, A., Rahmatullah, A. S., \& Sudrajat, S. 2020. Principals' personality, leadership, teachers' job satisfaction and students' achievement. International Journal of Psychosocial Rehabilitation, 24(08), 4581-4596. https://doi.org/10.37200/IJPR/V24I8/PR280475. 


\section{Fastabiq: Jurnal Studi Islam \\ ISSN 2723-0228}

Vol. 2 No. 1 Bulan Juni Tahun 2021

Prawira, Y. A. 2019. Menakar Kemampuan Literasi Pedagogi Guru Sekolah Dasar dalam Sudut Pandang Kompetensi Guru. Kewidyaiswaraan LAN, 4(1). Retrieved from http://u.lipi.go.id/1481869684

Prawira, Y. Andana. 2016. Kompetensi Evaluasi Pendidikan. Kemenag. Academia.Edu, (12).

Prawira, Y. A. 2018. GURU SEBAGAI PEMBANGUN PERADABAN BANGSA. SPS Pendidikan Bahasa Indonesia UPI.

Rahmat, A. D. N. 2015. Penggunaan permainan devinettes dalam pembelajaran menulis kalimat sederhana bahasa Prancis. Retrieved from repository.upi.edu

Salam, F. 2017. Kepemimpinan Spiritual Kepala Sekolah dalam Mengembangkan Profesionalisme Guru, 1(1). Fastabiq: Jurnal Pendidikan Islam. (1)1.

Setiawan, W. E. 2015. Model Pembelajaran Partisipatif dalam Meningkatkan Kemandirian Perempuan sebagai Kepala Keluarga. Universitas Negeri Palangkaraya.

Silva, E. 2009. Measuring Skills for 21st-Century Learning. Phi Delta Kappan, 90(9), 630-634. https://doi.org/10.1177/003172170909000905

Sterzik, V., Kneubuehl, B. P., Bohnert, M., Riva, F., \& Glardon, M. 2017. Bullet fragmentation preceding a contour shot: case study and experimental simulation. International Journal of Legal Medicine, 131(1), 173-177. https://doi.org/10.1007/s00414-016-1462-9

Utomo, A. P., \& PriskilaTehupeiory, K. (1858). Evaluasi Pelatihan dengan Metode Kirkpatrick Analysis, 9(2).

Wijaya, E. Y., Sudjimat, D. A., Nyoto, A., \& Malang, U. N. 2016. Transformasi pendidikan abad 21 sebagai tuntutan pengembangan sumber daya manusia di era global, 1, 263-278.

Yin, R. K. 1994. Discovering the Future of the Case Study. Method in Evaluation Research, 20814.

Zubaidah, S. 2016. Keterampilan Abad Ke-21: Keterampilan yang Diajarkan melalui Pembelajaran, (2), 1-17. Retrieved from siti.zubaidah.fmipa@um.ac.id 